\title{
PENCATATAN PERKAWINAN DAN PROBLEMATIKA KAWIN SIRI
}

\author{
M. Fahmi Al Amruzi \\ Fakultas Syari'ah UIN Antasari Banjarmasin \\ fahmialamruzi61@gmail.com
}

\begin{abstract}
Abstrak
Ketentuan aturan perkawinan diatur dalam undang-undang dan Peraturan Pemerintah Sedangkan aturan pelengkap yang akan menjadi pedoman bagi hakim di lembaga peradilan agama adalah Kompilasi Hukum Islam di Indonesia. Semuanya bertujuan untuk menjaga dan melindungi institusi perkawinan yang sakral dan kuat yang disebut dengan mitssaqan ghalidzan untuk menaati perintah Allah dan melaksanakannya merupakan ibadah. Sementara itu ada perkawinan yang disebut dengan perkawinan siri, perkawinan siri adalah perkawinan yang sah karena dilaksanakan sesuai dengan ketentuan hukum agama, yaitu dengan terpenuhinya rukun dan syarat perkawinan, hanya saja perkawinan tersebut tidak mendapat pengakuan negara karena tidak tercatat. Akibatnya perkawinan siri banyak menimbulkan problem terutama problem hukum dalam keluarga, seperti tidak adanya pengakuan hukum terhadap perkawinan tersebut dan problem lain yang mengikutinya seperti status anak yang tidak mendapatkan akte nikah, hak-hak keluarga lainnya terutama hak-hak perempuan (istri) dan anak yang sering tidak mendapat pengakuan dari bapak dan atau keluarga bapaknya seperti untuk mendapat hak nafkah dan waris dari bapaknya. Pencatatan perkawinan sesungguhnya adalah upaya untuk memberikan perlindungan hukum bagi keluarga terhadap hak-hak yang harus didapatkan sebagaimana mestinya dari sebuah perkawinan, dan pencatatan perkawinan meski tidak disyariat dalam agama Islam tetapi sesungguhnya tidak bertentangan dengan hukum Islam dan bahkan dianjurkan dengan tujuan menghindari kemudaratan dan problem yang mungkin akan terjadi di kemudian hari dalam keluarga.
\end{abstract}

Keyword: Keluarga, Kawin, Siri, Hukum Islam, Undang-Undang, Problem dan

Pencatatan.

\section{A. Pendahuluan}

Perkawinan merupakan salah satu dari tiga kejadian besar dalam hidup, seiring dengan kelahiran dan kematian. ${ }^{1}$ Perkawinan menurut hukum Islam adalah akad yang sangat kuat atau mitssaqan ghalidzan untuk mentaati perintah Allah dan melaksanakannya merupakan ibadah. Perkawinan bertujuan untuk mewujudkan kehidupan rumah tangga yang sakinah, mawaddah, dan rahmah. ${ }^{2}$

Melalui Perkawinan dua insan yang mempunyai banyak perbedaan, baik dari segi fisik, asuhan keluarga, pergaulan, cara berpikir (mental), pendidikan dan

1 Blood, R,0. 1969, Marriage ( $2^{\text {nd }}$ ed), New York, The Free Press

2 Intruksi Presiden Nomor 1 Tahun 1991, Tentang Kompilasi Hukum Islam, Pasal 2 dan 3 
perbedaan lainnya disatukan dan diktat dalam suatu ikatan suci untuk hidup bersama dengan direstui agama, kerabat dan masyarakat. ${ }^{3}$

Dalam Pasal 1 Undang-Undang Nomor 1 Tahun 1974 memberikan penjelasan, bahwa perkawinan adalah "ikatan lahir batin antara seorang pria dan seorang wanita sebagai suami istri dengan tujuan membentuk keluarga (rumah tangga) yang bahagia dan kekal berdasarkan Ketuhahan yang Maha Esa".

Ketentuan ini menegaskan bahwa perkawinan mempunyai hubungan yang erat sekali dengan agama/Kerohanian sehingga perkawinan tidak hanya mengandung unsur lahir dan jasmani, melainkan juga mengandung unsur batin/rohani ${ }^{4}$.

Melalui Pasal 2 ayat (1) Undang-Undang Nomor 1 Tahun 1974 tentang Perkawinan menjelaskan tentang keabsahan sebuah perkawinan. Isi pasal tersebut menegaskan bahwa "perkawinan dianggap sah apabila dilakukan menurut hukum masing-masing agamanya dan kepercayaannya itu". Dengan demikian bagi warga Indonesia yang beragama Islam berlaku hukum perkawinan Islam.

Selanjutnya Dalam Pasal 2 ayat (2) Undang-Undang Nomor 1 Tahun 1974 menjelaskan bahwa tiap-tiap perkawinan dicatat menurut peraturan perundangundangan yang berlaku. Dengan demikian setiap perkawinan harus didaftar dan dicatat oleh Pegawai Pencatat Nikah (PPN) di kantor pencatat nikah kecamatan sesuai dengan peraturan perundang-undangan. ${ }^{5}$

Terkait dengan ketentuan pasal 2 ayat (1) dan (2) Undang-undang perkawinan ini, sikap dan perlakuan masyarakat berbeda. Ketentuan hukum yang mengharuskan bahwa setiap perkawinan dilaksanakan sesuai dengan ketentuan agama berjalan dengan baik dan sangat ditaati dan bahkan hampir bisa dipastikan bahwa tidak ada perkawinan yang dilaksanakan yang tidak sesuai dengan ketentuan agama.

Kondisi sangat berbeda dengan penerapan pasal 1 ayat (2) yang mengharuskan bahwa setiap perkawinan harus dicatatkan. Fenomena yang terjadi justru menunjukkan masih banyak terjadi perkawinan yang tidak tercatatkan dengan berbagai faktor dan alasan penyebabnya. Padahal dengan melalui pencatatan sebagaimana dikehendaki pasal 2 ayat (2) tersebut eksistensi perkawinan dan keluarga mendapatkan jaminan kepastian dan perlindungan hukum, perkawinan

${ }^{3}$ Enseklopedia Pengetahuan Al-Qur'an dan Hadis, (Jakarta: Kamil Pustaka, 2013), h. 294-295

${ }^{4}$ Moh Idris Ramulyo. 1996. Hukum perkawinan Islam Suatu Analisis dari Undang-Undang Nomor 1 Tahun 1974 dan Kompilasi Hukum Islam. Jakarta : Bumi Aksara, hlm. 2.

5 Undang-undang RI No. 1 Tahun 1974 Tentang perkawinan \& KHI Cet. II (Bandung: Citra Umbara, 2013), h. 2 
tanpa pencatatan akan berdampak ilegalnya sebuah perkawinan tentu saja dengan segala akibatnya. Sementara itu di dalam pasal 5 Kompilasi Hukum Islam ditegaskan: "Agar terjamin ketertiban perkawinan bagi masyarakat Islam setiap perkawinan harus di catat"6

Perkawinan yang tidak dicatatkan sesuai dengan ketentuan hukum yang berlaku sering disebut dengan kawin siri. Dimaksudkan dengan kawin siri di sini adalah perkawinan yang sah yang dilaksanakan sesuai dengan rukun dan syarat perkawinan yang dituntut menurut ketentuan agama (sesuai dengan ketentuan pasal 2 ayat (1) Undang-undang perkawinan, akan tetapi perkawinan tersebut tidak dicatatkan sebagaimana dikehendaki pada apas 2 ayat (2) Undang-undang perkawinan karena ada suatu tertentu. Sebutan lain dari kawin siri ini adalah nikah di bawah tangan.

Fenomena yang terjadi di tengah masyarakat menunjukkan bahwa kawin siri sering terjadi dengan berbagai alasan dan faktor penyebabnya, begitu pula dengan berbagai problem yang ditimbulkannya.

Pencatatan perkawinan sesungguhnya sama pentingnya dengan nilai keabsahan sebuah perkawinan karena perkawinan yang bertujuan untuk membentuk rumah tangga yang tenteram, bahagia, sakinah, mawaddah wa rahmah tidak mungkin terlaksanakan kalau tidak didasari oleh keabsahan perkawinan itu sendiri, demikian juga halnya dengan jaminan dan kepastian dari eksistensi sebuah keluarga yang terbangun dari perkawinan yang secara legal tidak pernah mendapat pengakuan oleh negara karena secara administrasi tidak pernah tercatat. Perkawinan seperti ini justru akan mendatang problem keluarga, terutama yang terkait dengan hak anak dan perempuan yang dinikahi sebagai istri.

Akibat dari sebuah perkawinan yang tidak tercatat yang terkait dengan anak yang dilahirkan, sang anak akan mengalami diskriminasi pemenuhan dan perlindungan hak anaknya yang mencakup relasi dalam hukum keluarga, termasuk hak-hak anak atas pelayanan sosial, pendidikan, dan pencatatan kelahiran. Padahal, setiap anak yang dilahirkan membawa hak-haknya sendiri yang melekat (rights of the child) yang pada prinsipnya tidak boleh diperlakukan berbeda atau diskriminasi.

Demikian juga perkawinan tidak tercatat berdampak buruk kepada perempuan sebagai istri, kedudukan perempuan sebagai istri menjadi tidak diakui oleh negara. Seorang istri berada pada posisi yang sangat lemah dan dirugikan, 
sebagai seorang istri tidak mendapat jaminan dan perlindungan atas hak-haknya dalam perkawinan.

Tulisan ini mencoba memberikan analisa dan gambaran tentang betapa pentingnya arti pencatatan dalam perkawinan, dan menjelaskan terkait dengan problem yang terjadi sebagai dampak negatif dari praktik perkawinan siri yang tidak dicatatkan.

\section{B. Pencatatan Perkawinan}

Hukum Islam yang terkait dengan struktur keluarga di antaranya adalah hukum perkawinan dan kewarisan dengan berbagai derivasinya yang merupakan hak perdata dalam hukum Islam; menyangkut hak nasab, hak perwalian, hak memperoleh nafkah dan hak mendapatkan warisan. Bahkan konsep kemahraman atau kemuhriman dalam Islam akibat hubungan persemendaan atau perkawinan. ${ }^{7}$ Dalam surah Al-Furqan ayat 54 Allah berfirman:

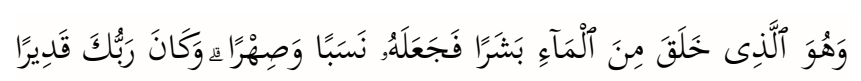

artinya "Dan Dia (pula) yang menciptakan manusia dari air lalu Dia jadikan manusia itu (punya) keturunan dan mushaharah dan adalah Tuhanmu Maha Kuasa”. ${ }^{8}$ (QS. Al-Furqan: 54)

Pemerintah Republik Indonesia melalui Pasal 2 ayat (1) Undang-Undang Nomor 1 Tahun 1974 tentang Perkawinan telah menegaskan bahwa perkawinan dianggap sah apabila dilakukan menurut hukum masing-masing agamanya dan kepercayaannya itu. Dengan demikian bagi warga negara Indonesia yang beragama Islam berlaku hukum perkawinan Islam, dan perkawinan tersebut harus dicatatkan menurut peraturan perundang-undangan yang berlaku sebagaimana dikehendaki pasal 2 ayat (2) Undang-Undang Nomor 1 Tahun $1974 .{ }^{9}$

Pelaksanaan pencatatan perkawinan tersebut kemudian diatur dalam Peraturan Pemerintah Nomor 9 Tahun 1975 Tentang Pelaksanaan Undang- Undang Nomor 1 Tahun 1974 Tentang Perkawinan. Pasal 2 Peraturan Pemerintah tersebut menegaskan bahwa pencatatan perkawinan bagi mereka yang melangsungkan

${ }^{7}$ M. Nurul Irfan, Nasab dan Status Anak dalam Hukum Islam, (Jakarta: Amzah, 2013), h. 7.

8 Departeman Agama RI, Al-Qur'an Tajwid dan Terjemah, (Jakarta: Penerbit Maghfirah Pustaka, 2006), h. 366.

${ }^{9}$ Undang-Undang RI Nomor 1 Tahun 1974, Loc. cit 
perkawinan menurut agama Islam dilakukan oleh pegawai pencatat nikah ${ }^{10}$ sebagaimana dimaksud dalam Undang-Undang Nomor 22 Tahun 1946 jo Nomor 32 Tahun 1954 Tentang Pencatatan Nikah, Talak dan Rujuk. ${ }^{11}$ Sedangkan bagi mereka yang tidak beragama Islam (non muslim), pencatatannya dilakukan oleh pegawai pencatat perkawinan pada kantor catatan sipil. ${ }^{12}$

Pencatatan perkawinan bertujuan untuk tertib administrasi, juga bertujuan untuk melindungi hak-hak orang yang melaksanakan perkawinan, serta sebagai bukti bahwa benar-benar telah terjadi perkawinan. ${ }^{13}$ Setiap perkawinan yang dilaksanakan di Indonesia harus dicatatkan sesuai dengan peraturan dan perundangundangan. Perkawinan yang tidak dicatatkan atau dilakukan di luar pengawasan pegawai pencatat nikah dianggap tidak mempunyai kekuatan hukum. ${ }^{14}$

Dalam hukum Islam tidak dikenal adanya pencatatan perkawinan, pencatatan perkawinan di wajib oleh undang-undang tersebut, secara tegas hukum pencatatan perkawinan tidak dikenal dalam hukum Islam sehingga tidak ditemukan pembahasannya di dalam kitab-kitab fikih, namun dari aspek tujuannya selaras dan sejalan dengan tujuan dari hukum Islam itu sendiri, seperti untuk kemaslahatan keluarga dalam rangka menertibkan perkawinan sehingga diharapkan tidak akan terjadi perkawinan dengan calon suami/istri yang terlarang untuk kawin, atau terjadi kesalahan wali dan lain sebagainya akibat dari tidak diketahui identitas para pihak. Akibat lainnya adalah adanya pihak-pihak yang dirugikan di kemudian hari yang disebabkan tidak adanya perlindungan hukum, karena adanya orang yang dimintai pertanggungjawaban dalam perkawinan tersebut.

Dengan demikian maka pencatatan perkawinan yang bertujuan untuk tertibnya administrasi perkawinan memiliki tujuan yang sama dengan tujuan hukum Islam yaitu menciptakan kemaslahatan dan menghindari kemudaratan, oleh karenanya pencatatan perkawinan searah dengan maqashid syari'ah. yang

10 Peraturan Pemerintah Nomor 9 Tahun 1975 tentang Pelaksanaan Undang-Undang Nomor 1 Tahun 1974 tentang Perkawinan, Pasal 2

11 Undang-undang Nomor 22 Tahun 1946 jo Undang-undang Nomor 32 Tahun 1954 tentang Pencatatan Nikah, Talak dan Rujuk di Seluruh Daerah Luar Jawa dan Madura

12 Muhammad Amin Suma, Hukum Keluarga Islam Di Dunia Islam, (Jakarta:PT Raja Grafindo Persada, 2004), h. 235.

13 Intruksi Presiden Nomor 1 Tahun 1991, Op Cit

14 Ibid., Pasal 6 ayat (1). 
merupakan prinsip dasar dalam pembentukan hukum Islam.

Sebaliknya perkawinan yang sudah sah dilaksanakan sesuai dengan ketentuan hukum Islam tetapi tidak dicatatkan, tidak menutup kemungkinan dikemudian hari ada perkawinan yang harus dibatalkan (difasakh) yang disebabkan karena terjadinya perkawinan dengan calon suami/istri yang ternyata termasuk perkawinan yang terlarang baik karena se mahram atau terjadi kesalahan dalam perwalian.

Pembatalan perkawinan (fasakh) terhadap perkawinan yang telah berlangsung berdampak bagi sebuah keluarga, lebih-lebih kalau keluarga tersebut telah melahirkan keturunan, oleh karenanya menghindari kemudaratan dengan cata pencatatan dalam perkawinan lebih dianjurkan. Demikian juga dalam kaitannya dengan keperdataan lainnya, akibat tidak adanya pencatatan sebagai data autentik dalam perkawinan akan ada pihak-pihak yang dirugikan karena lemahnya jaminan perlindungan hukum terhadapnya.

Dalam pandangan hukum Islam pencatatan perkawinan bisa ditetapkan dengan menggunakan teori qiyas atau teori maslahah mursalah, teori Syaddu al Zari'ah, teori Istihsan atau juga teori lainnya, maka dengan demikian pencatatan perkawinan pun adalah bagian dari hukum Islam yang bertujuan untuk menjaga keutuhan perkawinan yang merupakan sunah yang harus dipertahankan, bahkan diingat bahwa perpisahan atau perceraian itu boleh tetapi tidak diharapkan karena akan mengundang murkanya Allah.

Pencatatan perkawinan mengandung banyak kebaikan, kemaslahatan dan kemanfaatan bagi keluarga, dengan pencatatan perkawinan masing-masing pihak anggota keluarga terlindungi, baik pada saat perkawinan itu berlangsung maupun pasca perkawinan.

Perkawinan dalam arti akad yang sangat kuat, disebut dengan mitssaqan ghalidzan untuk menaati perintah Allah dan melaksanakannya merupakan ibadah, dengan tujuan untuk terwujudnya kehidupan rumah tangga yang sakinah, mawaddah, dan rahmah ${ }^{15}$. Dalam surah Ar Rum ayat 21 Allah berfirman: 


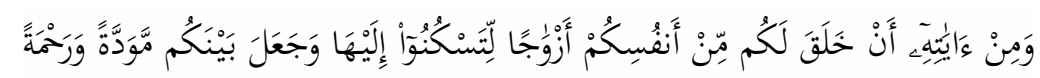

"Dan di antara ayat-ayat-Nya ialah Dia menciptakan untukmu istri-istri dari jenismu sendiri, supaya kamu merasa nyaman kepadanya, dan dijadikan-Nya di antaramu mawadah dan rahmah".16

Sesungguhnya dalam pasal 1 Undang-Undang Nomor 1 Tahun 1974 Tentang Perkawinan menyebutkan dasar perkawinan dan juga menyebutkan tujuan dari perkawinan: "Perkawinan ialah ikatan lahir batin antara seorang pria dengan seorang wanita sebagai suami istri dengan tujuan untuk membentuk keluarga (rumah tangga) yang bahagia dan kekal berdasarkan Ketuhanan Yang Maha Esa” 17

Pasal 1 Undang-Undang Perkawinan ini secara terbuka menyebutkan dua tujuan dari perkawinan, yaitu:

1. Keluarga yang bahagia, dan

2. Keluarga yang kekal.

Untuk mewujudkan tujuan perkawinan tersebut di atas baik menurut $\mathrm{Al}$ Qur'an maupun tujuan perkawinan yang disebutkan dalam Undang-Undang perkawinan tidak cukup dengan sekedar bahwa perkawinan itu sah, tetapi juga harus legal melalui pencatatan, sehingga akan mendapatkan jaminan dan perlindungan hukum dari negara, sehingga dalam pasal 2 ayat (2) disebutkan bahwa setiap perkawinan itu harus dicatatkan.

Kawin siri meskipun sah tetapi sering kali melahirkan problem di kemudian hari dan dapat dihindari melalui pencatatan pernikahan, menghindari problem/mudarat lebih diutamakan, dan setiap kemudaratan harus dihilangkan, demikian yang ditegaskan dalam prinsip-prinsip pembentukan hukum Islam.

Beberapa prinsip atau kaidah-kaidah usul fikih dapat dijadikan acuan utama dalam menentukan berbagai aturan untuk menghindari mudarat atau problem dalam hidup, seperti kaidah:

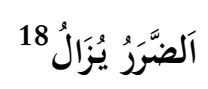

16Departeman Agama RI, Loc Cit, h. 406.

17Undang-undang RI No. 1 Tahun 1974, Loc. cit

${ }^{18}$ Ahmad al Hajjiy al Kurdiy, Al Qawa'id al Fiqhiyatu al Kulliyah, Cet. I, 2019 M/1440 H. Al Dar Al Thahiriyah, Kuwait, h. 43 
Artinya: Kemudaratan harus dihilangkan

Kaidah lainnya yang juga bisa digunakan dalam pembentukan hukum Iskam adalah:

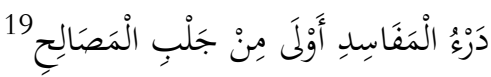

Artinya: Menolak kerusakan harus didahulukan daripada menarik kemaslahatan

\section{Kawin Siri}

Kata siri secara etimologis berasal dari bahasa Arab "sirrun" berarti rahasia atau sesuatu yang disembunyikan ${ }^{20}$. Melalui akar kata ini nikah siri diartikan sebagai nikah yang dirahasiakan, berbeda dengan nikah pada umumnya yang dilakukan secara terang-terangan ${ }^{21}$ Jadi nikah siri berarti nikah rahasia (secret marriage), pernikahan yang dirahasiakan dari pengetahuan orang banyak. ${ }^{22}$

Terminologi nikah siri di Indonesia kemudian menjalani penyesuaian makna, sebelumnya diungkapkan oleh Abdul Ghofir Anshori bahwa pada umumnya yang dimaksud dengan Perkawinan siri adalah perkawinan yang dilakukan menurut syariat Islam, tetapi tidak / belum dicatatkan oleh Pegawai Pencatat Nikah (PPN) ${ }^{23}$

Dalam terminologi fikih Maliki, nikah (kawin) siri ialah nikah yang karena pesan dari pihak suami, para saksi merahasiakannya untuk istrinya atau jamaahnya termasuk keluarga setempat. ${ }^{24}$

Dalam sejarah perkawinan siri sudah dikenal sejak zaman Khalifah Umar bin Khattab sebagaimana dikutip oleh Imam Malik dalam Kitab Al Muwatha'nya. ${ }^{25}$ Dalam kajian hukum Islam tentang perkawinan siri yang pada awalnya perkawinan siri ditujukan perkawinan yang tidak memenuhi rukun dan syarat perkawinan,

${ }^{19}$ Muhammad Utsman Syabir, al-Qawấid al- Kulliyah wa al-DLawâbith al-Fiqhiyyah, (Urdun: Dar al Nafais, 2007) h. 164

20 Ahmad Warson Munawwir, Al-Munawwir, (Surabaya, Pustaka Progressif, 1997), h. 626.

${ }^{21}$ M.Ali Hasan, Pedoman Hidup Berumah Tangga Dalam Islam, (Jakarta: Prenada Media, 2003), h. 295

22 Abdul manan, Aneka Masalah Hukum Perdata Islam Di Indonesia, (Jakarta, Kencana Prenada Media Group, 2006) Cet. I, Ed. Pertama, h. 47-48

${ }_{23}$ Abdul Ghofur Ansori, Hukum Perkawinan Islam: Prespektif Fikih dan Hukum Positif, cet 1, (Yogyakarta:UUI Press, 2011), hlm. 169

${ }^{24}$ Masyfuk Zuhdi, Nikah Sirri, Nikah Di Bawah Tangan Dan Status Anaknya Menurut Hukum Islam Dan Hukum Positif, dalam Mimbar Hukum h. 110-112, Nomor 28 Tahun VII, September - Oktober 1996, Jakarta, Al Hikmah Dan DITBINBAPERA Islam.

${ }^{25}$ Sujari Dahlan, Fenomena Nikah Sirri, Cet. I, Pustaka Progresif, 1996, h. 31 
sebagaimana dikemukakan oleh Umar bin Khattab ketika beliau menerima pengaduan tentang perkawinan yang hanya disaksikan oleh seorang laki-laki dan seorang perempuan. ${ }^{26}$

Kawin siri yang dikenal pada masa khalifah Umar tersebut adalah perkawinan yang tidak dapat dianggap sah karena tidak menghadirkan rukun dan syarat nikah yang sempurna sebagaimana yang dikehendaki dalam ketentuan agama, ${ }^{27}$

Menurut Jumhur (Madzhab Hanafi, Syafi'i, dan Hanbali), kawin siri atau nikah siri adalah nikah yang tidak dihadiri oleh saksi, maka ketika dihadiri saksi, maka statusnya merupakan nikah alaniyah (yang diumumkan) sebagaimana pada umumnya. Jadi ketika terjadi pernikahan kurang dari dua saksi laki-laki, maka Jumhur mengklasifikasikannya sebagai Nikah Siri. Nikah siri sebagaimana yang telah dijelaskan tersebut merupakan sebuah pernikahan yang batal dan tidak sah karena tidak adanya saksi. ${ }^{28}$

Menurut Mahmud Syaltūt perkawinan siri adalah salah satu bentuk perkawinan jenis lama yang sudah lama dijelaskan definisi dan hukumnya oleh fuqaha. Fuqaha tradisional telah menyepakati bahwa perkawinan siri adalah akad nikah oleh dua belah pihak tanpa ada saksi, pengumuman, tanpa penulisan buku resmi, dan pasangan tetap hidup dalam kondisi yang disembunyikan. Lebih lanjut, Syaltūt berpendapat bahwa tujuan pencatatan perkawinan adalah untuk memelihara hak-hak dan kewajiban para pihak dalam perkawinan yaitu hak suami istri dan anakanak sebagai keturunan seperti pemeliharaan, warisan, dan perwalian. ${ }^{29}$

Perkawinan siri ini berbeda dengan nikah siri yang dikenal di Indonesia. kawin siri dalam terminologi hukum di Indonesia adalah kawin secara rahasia dalam arti kawin yang tidak formal dan sering juga disebut dengan kawin bawah tangan, disebut dengan nikah bawah tangan karena yang menikahkan dalam perkawinan tersebut adalah orang tua atau wali secara langsung tanpa adanya prosedur pencatatan secara resmi sesuai ketentuan undang-undang.

\footnotetext{
26 Dr. H. Saifudin zuhri, M.Ag, Sanksi Pidana Sebagai Pendidikan Bagi Pelaku Nikah Siri Dalam Perspektif Hukum Islam, (Semarang, 2012) h. 19-20

27 Sujari Dahlan, Fenomena Nikah Sirri, Cet. I, Pustaka Progresif, 1996, h. 31

${ }^{28}$ Al Munawar, Faishal Agil, Telaah Fatwa tentang Nikah Siri, Istidlal: Jurnal Ekonomi dan Hukum Islam Volume 4, Nomor 1, April 2020, h. 58

${ }^{29}$ Nasotion, Khoiruddin, Hukum Perdata (Keluarga) Islam Indonesia dan Perbandingan Hukum Perkawinan Di Dunia Muslim, Yogyakarta: Academia Tazzafa, 2009, h.
} 
Perkawinan siri seperti ini sesungguhnya adalah perkawinan yang sah karena memenuhi ketentuan agama yaitu dengan terpenuhinya rukun dan syarat dari sebuah perkawinan hanya saja perkawinan ini tidak dicatatkan sehingga perkawinan siri ini tidak memiliki kekuatan dan perlindungan hukum.

Secara administrasi negara, perkawinan seperti ini tergolong perkawinan yang melanggar ketentuan peraturan yang berlaku. Dengan demikian, perkawinan siri bisa dikatakan adalah sebuah perkawinan yang tidak mematuhi atau tidak menaati peraturan hukum yang sah yang diatur oleh negara.

Dalam kenyataannya, praktik perkawinan nikah siri ini masih sering terjadi di masyarakat dan dapat disaksikan di hampir di seluruh penjuru di Indonesia, buktinya dalam kondisi tertentu adanya permohonan isbat nikah di Pengadilan Agama untuk kepentingan tertentu yang menuntut adanya akte nikah. Banyak faktor yang melatarbelakangi terjadinya perkawinan siri atau bawah tangan; di antaranya karena faktor usia calon yang berada di bawah usia yang ditetapkan oleh undang-undang, faktor berpoligami yang tidak mendapat izin dari istri pertama dan faktor-faktor lainnya.

Persoalan yang menarik untuk dipertanyakan adalah apakah karena ketentuan hukumnya yang tidak tegas atau secara tersirat dan tersurat, bahwa sebenarnya pemerintah melegalkan praktik pernikahan tidak tercatat ini melalui peraturan-peraturan tersebut, atau bahkan keduanya, atau mungkin karena kultur masyarakat (legal culture) yang terbiasa mengabaikan atau menganggap gampang sehingga tidak mencatatkan perkawinannya, ataukah juga karena faktor ekonomi dan pemahaman lainnya, seperti pemahaman kepercayaan dan keagamaan.

Praktik nikah atau kawin tidak tercatat ini sebenarnya sudah pernah disahkan oleh Negara melalui Mahkamah Islam, sebelum keluarnya Undang-Undang Nomor 1 Tahun 1974. Berdasarkan keputusan Mahkamah Islam Tinggi No.23/19 Tahun 1953 menegaskan bahwa bila rukun nikah telah lengkap, tetapi tidak didaftarkan, maka nikah tersebut tetap sah, namun yang bersangkutan dikenakan denda karena tidak didaftarkannya nikah itu. ${ }^{30}$

30 Abd. Somad, Hukum Islam, Penormaan Prinsip Syariah dalam Hukum Islam Indonesia (Cet.I; Jakarta: Kencana Predana Group), h. 295. 


\section{PROBLEMATIKA KAWIN SIRI}

Kawin siri dimaksudkan di sini adalah sebagaimana perkawinan pada umumnya yaitu yang dilaksanakan dengan memenuhi semua rukun dan syarat perkawinan sebagaimana yang dituntut sesuai dengan ketentuan hukum agama Islam, hanya saja proses perkawinannya tidak dicatatkan dalam daftar catatan perkawinan di Kantor Pencatatan Perkawinan dan tidak memiliki surat/akte nikah yang dikeluarkan oleh pemerintah.

Pihak yang paling dirugikan dalam perkawinan siri adalah perempuan, sering kali hak-hak perempuan pada perkawinan siri terabaikan dan tidak mendapatkan jaminan, karena rumah tangga yang dibangun dengan perkawinan siri itu sendiri tidak mendapatkan perlindungan hukum, lebih-lebih lagi apabila keluarga dari perkawinan siri itu telah mendapat keturunan (anak) dan dampak negatifnya tidak hanya kepada perempuan tetapi juga berujung pada anak.

Problem yang dihadapi oleh anak akan mulai terasa ketika orang tuanya bercerai atau salah satunya meninggal dunia, bapak atau keluarga bapaknya tidak mengakuinya, hak ibu dan anaknya sulit dan bahkan tidak didapatkan, sehingga segala fasilitas pendukung hidupnya terputus.

Meskipun sebenarnya hubungan anak dengan ayah dan ibunya secara syariat Islam tidak ada masalah dan diakui tetapi apabila dihadapkan dengan hukum Negara, hubungan keperdataan dengan ayah biologisnya tidak dapat diakui.

Anak yang dilahirkan dari perkawinan tersebut oleh negara dianggap sebagai anak luar kawin (tidak sah) dan dampaknya adalah bahwa anak tersebut hanya memiliki hubungan hukum keperdataan dengan ibu dan keluarganya sedang hubungan perdata dengan ayahnya tidak ada sebagaimana disebutkan dalam pasal 42 dan 43 UUP dan pasal $100 \mathrm{KHI}$, disebutkan anak luar kawin dalam pasal 43, adalah:

1. Anak yang dilahirkan di luar perkawinan hanya mempunyai hubungan perdata dengan ibunya dan keluarga ibunya;

2. Kedudukan anak tersebut ayat (1) di atas selanjutnya akan diatur dalam peraturan Peraturan Pemerintah.

Sebuah kenyataan dan sering terjadi, rumah tangga dari perkawinan siri ini, istri dan anaknya dengan mudah dan kapan saja bisa ditinggalkan oleh 
suaminya, sementara istri dan anaknya tidak dapat berbuat banyak untuk menuntut hak-haknya, seperti tuntutan berupa biaya pemeliharaan (hadlanah) dan berupa tunjangan finansial untuk membesarkan anak dari mantan suaminya, problem lainnya adalah yang terkait dengan hak anak untuk mendapatkan akta kelahiran, demikian juga dengan hak waris yang sulit diwujudkan pada saat sang ayah sebagai orang tua kandungnya meninggal dunia, padahal tidak dapat disangkal dan dipungkiri bahwa anak yang lahir dari perkawinan siri ini memiliki hubungan darah dan keturunan sebagai anak dengan ayahnya.

Salah satu kasusnya adalah yang pernah dialami oleh Hj. Aisyah Mokhtar dan anaknya yang bernama Muhammad Iqbal Ramadhan bin Moerdiono yang berakhir dengan lahirnya Putusan Mahkamah Konstitusi RI Nomor 46/PUU-VII/2010 tanggal 27 Februari 2012 setelah mengajukan yudisial review terhadap ketentuan Pasal 2 ayat (2) dan Pasal 43 ayat (1) Undang-Undang Nomor 1 Tahun 1974 tentang Perkawinan, dengan duduk masalahnya adalah dimana Moerdiono sebagai seorang suami yang telah beristri dan menikah kembali dengan seorang perempuan yang bernama Hj. Aisyah Mokhtar secara syariat Islam sebagai istri kedua dengan siri dan tidak dicatat sesuai dengan ketentuan yang berlaku di Kantor Pencatatan nikah dalam Hal di KUA.

Demikian juga hal serupa banyak terjadi di masyarakat kasus-kasus serupa dengan problem yang berbeda-beda; ada problem seorang anak yang tidak bisa didaftarkan disekolah karena tidak memiliki identitas kelahiran (akte lahir) akibat dari perkawinan orang tuanya kawin siri (tidak tercatat); ada kasus anak terlantar karena ditinggal mati oleh ayahnya dan tidak diakui sebagai anak oleh keluarga (saudara seayah) akibat ayahnya kawin dengan ibunya tanpa dicatatkan di kantor pencatatan perkawinan; dan sederet kasus lainnya yang terjadi dimasyarakat seperti tidak adanya perlindungan hukum terhadap perempuan sebagai istri yang ditinggalkan/ditelantarkan oleh suami sirinya.

Meski demikian problem terkait dengan persoalan perkawinan siri terus saja terjadi, karena dalam konteks pemahaman keabsahan perkawinan baik dari persepsi masyarakat dan bahkan dalam persepsi hukum pun perkawinan siri adalah perkawinan yang sah karena dilakukan sesuai dengan ketentuan hukum agama yaitu terpenuhinya semua rukun dan syarat perkawinan, sebagaimana yang dikehendaki pada pasal 2 ayat (1) Undang-Undang Nomor 1 tahun 1974), kecuali pada ayat (2) dalam pasal 2 Undang-Undang tersebut menyebutkan bahwa perkawinan yang sah tersebut harus dicatatkan, demikian ketentuan pasal 2 ayat (2) Undang-Undang 
Perkawinan.

Pasal 2 ayat (1) Undang-undang perkawinan ini terkait dengan substansi perkawinan yang menentukan sah dan tidak sahnya perkawinan, sementara pada ayat (2) berikutnya menjelaskan terkait dengan administrasi perkawinan, yang merupakan pengakuan dari eksistensi sebuah perkawinan oleh negara.

Kondisi seperti ini terus saja terjadi, perkawinan tidak tercatat sebagaimana yang dikehendaki dalam pasal 2 ayat (2), yang dikatakan sebagai kawin siri dengan segala problematika juga terus saja terjadi sampai pada puncaknya dan muncul kepermukaan dengan melibatkan Mahkamah Konstitusi untuk menguji materi hukumnya.

\section{E. Putusan Mk}

Kasus terkait dengan persoalan kawin siri dengan problematiknya yang akhirnya harus diselesaikan melalui Mahkamah Konstitusi di antaranya adalah Kasus Hj. Aisyah Mochtar alias Machica binti H. Mochtar Ibrahim bersama kuasa hukumnya yang memperjuangkan status hukum anaknya bernama Muhammad Iqbal Ramadhan bin Moerdiono buah dari perkawinan sirinya dengan Moerdiono, yang mengakibatkan anak tersebut tidak mendapatkan pengakuan status keperdataan dari ayah biologisnya sehingga tidak mendapatkan hak waris yang semestinya menjadi hak anak tersebut. ${ }^{31}$

Amar putusan MK menyatakan mengabulkan permohonan pemohon untuk sebagian, yaitu pada Pasal 43 ayat (1) yang menyatakan "Anakyang dilahirkan di luar perkawinan hanya mempunyai hubungan perdata dengan ibunya dan keluarga ibunya", bertentangan dengan UUD RI tahun 1945 sepanjang dimaknai menghilangkan hubungan perdata dengan laki-laki yang dapat dibuktikan berdasarkan ilmu pengetahuan dan teknologi dan/atau alat bukti lain menurut hukum ternyata mempunyai hubungan darah dengan ayahnya. Sehingga ayat tersebut harus dibaca "Anak yang dilahirkan di luar perkawinan mempunyai hubungan perdata dengan ibunya dan keluarga ibunya serta dengan laki-laki sebagai ayahnya yang dapat dibuktikan berdasarkan ilmu pengetahuan dan teknologi

${ }^{31}$ http://tribunnews.com/seleb/2013/04/24/anak-machica-mochtar-tak-dapat-warisanmoerdiono. 
dan/atau alat bukti lain menurut hukum mempunyai hubungan darah, termasuk hubungan perdata dengan keluarga ayahnya".32

Amar putusan selanjutnya berbunyi, dan menolak permohonan para pemohon untuk selain dan selebihnya, yaitu berkaitan dengan Pasal 2 ayat (2) UUP No. 1 Tahun 1974 tentang pencatatan perkawinan. ${ }^{33}$ Alasan penolakan MK karena pencatatan perkawinan merupakan kewajiban administratif yang harus dipenuhi oleh setiap warga negara Indonesia. Tujuannya sesuai dengan tanggung jawab negara pada warga negaranya yaitu untuk memberikan jaminan perlindungan, pemajuan, penegakan, dan pemenuhan hak asasi manusia yang bersangkutan. Perkawinan adalah suatu perbuatan hukum. Oleh karena itu, pencatatan perkawinan merupakan suatu akta autentik. Sehingga perlindungan dan pelayanan oleh negara terkait dengan hak-hak yang timbul dari suatu perkawinan yang bersangkutan dapat terselenggara secara efektif dan efisien. ${ }^{34}$

Putusan MK No. 46/PUU-VIII/2010 adalah sebuah putusan yang memberi warna paradigma baru dalam sistem hukum perdata dan hukum keluarga khususnya yang berlaku di Indonesia. Putusan MK tidak hanya mengikat para pihak yang terlibat dalam perkara (intra partes), tetapi juga harus ditaati oleh siapa pun disebut dengan putusan yang bersifat erge omnes. Ketentuan mengikat umum putusan MK ini dikarenakan sifat hukum publiknya. ${ }^{35}$

Dengan demikian, maka Putusan MK No. 46/PUUVIII/2010 merupakan putusan yang bersifat final and binding. Bersifat mengikat, dan tidak adanya upaya hukum lebih lanjut, seperti banding, kasasi, ataupun peninjauan kembali dari Putusan yang sudah dibacakan untuk umum.

Secara tekstual, putusan MK tersebut menjelaskan bahwa frasa "anak yang dilahirkan di luar perkawinan" minimal mengandung 2 (dua) makna :

1. anak yang dilahirkan dari pernikahan yang sah menurut agama namun tidak dicatatkan pada lembaga yang berwenang, mengingat pemohon yang mengajukan permohonan judicial review pada MK berangkat dari pemaknaan nikah siri dan

32 Putusan MK No. 46/PUU-VIII/2010, h. 36-37

33 Ibid., h. 37

34 Ibid., h. 33-34

35 Maruara Siahaan, Hukum Acara Mahkamah Konstitusi (Jakarta: Sinar Grafika, 2012), h. 160. 
atau perkawinan tidak tercatat sebagaimana maksud Undang-undang Perkawinan No. 1 Tahun 1974 Pasal 2 ayat (2) dan Pasal 43 ayat (1);

2. anak yang lahir tanpa adanya ikatan perkawinan seperti kumpul kebo, perselingkuhan dan sebagainya, dikarenakan tidak adanya penegasan dan/atau penjelasan terkait makna tersebut pada amar putusan MK .

Putusan MK ini menimbulkan kontroversi sekaligus berdampak luas bagi masyarakat, antara lain terkesan tetap mewajibkan pencatatan perkawinan sebagai kewajiban administratif yang harus dipenuhi dan akta autentik bagi setiap warga negara Indonesia akan berakibat ketidakpastian status hukum perkawinan tidak tercatat atau nikah siri dan anak yang lahir akan mengalami kesulitan dalam mendapatkan identitas catatan sipil berupa akta kelahiran. Padahal akta kelahiran merupakan hak anak pertama yang seharusnya diberikan oleh negara. Undangundang Dasar dan Undang-undang perlindungan anak menyatakan dengan jelas bahwa setiap anak dengan jelas berhak mendapatkan identitas, pengakuan, jaminan, perlindungan, dan kepastian hukum yang adil dari Negara. Identitas atas kelahiran merupakan suatu bentuk pengakuan dari orang tua dan juga jaminan dari negara.

\section{F. Penutup}

Nikah/kawin siri adalah perkawinan yang dirahasiakan karena ada tujuantujuan tertentu dibalik perkawinan tersebut sehingga tidak diformalkan sebagai sebuah perkawinan yang dicatat dalam administrasi negara dan akibatnya perkawinan tersebut tidak mendapatkan akte nikah sebagai bukti terjadinya perkawinan yang sah.

Perkawinan siri sesungguhnya adalah perkawinan yang sah menurut ketentuan agama meski menurut ketentuan peraturan perundang-undangan dianggap tidak pernah terjadi karena perkawinan itu tidak dicatatkan, oleh karenanya negara tidak dapat hadir untuk memberikan perlindungan hukum kalau terjadi sengketa hukum terhadap keluarga tersebut. Akibatnya segala yang lahir dari perkawinan tersebut di nilai tidak ada dan tidak mendapat perlindungan karena perkawinan tersebut tidak mendapatkan pengakuan hukum, seperti kelahiran anak, perceraian, atau salah satu dari suami istri tersebut ada yang meninggal dunia, akan 
menjadi problemnya sendiri.

Seorang anak yang terlahir dari keluarga yang dilaksanakan melalui nikah/kawin siri tidak mendapatkan pengakuan sebagai anak yang sah karena dianggap sebagai anak luar nikah dan akibatnya sang anak tidak mendapatkan akte kelahiran, demikian juga kalau bapaknya meninggal maka sang anak sulit untuk mendapatkan hak warisnya karena sering kali dianggap sebagai anak luar nikah oleh keluarga bapaknya, karena memang secara perdata dia hanya memiliki hubungan perdata dengan ibu dan keluarga ibunya saja.

Demikian juga dengan seorang istri sulit untuk memperjuangkan hak-haknya yang didapat selama berkeluarga baik berupa harta warisan atau harta kekayaan selama perkawinan kalau rumah tangganya berakhir.

Problem lain yang lahir akibat perkawinan/pernikahan siri tidak hanya berakhir sampai di situ dan mungkin akan menimbulkan problem lainnya di kemudian hari jauh setelah sang suami/ayah meninggal dunia, seperti terjadinya kawin bersaudara ketika sang ayah kawin poligami siri, antara satu anak dengan anak yang lain dari istri yang lain melakukan perkawinan dan ternyata akhirnya diketahui kalau pasangan suami istri tersebut bersaudara seayah. Dan tidak menutup kemungkinan seorang anak kawin dengan mantan istri ayahnya (ibu tiri) dan problem-problem lainnya dalam keluarga. 


\section{DAFTAR PUSTAKA}

Abd. Somad, Hukum Islam, Penormaan Prinsip Syariah dalam Hukum Islam Indonesia, Cet.I; Jakarta: Kencana Predana Group

Abdul manan, Aneka Masalah Hukum Perdata Islam Di Indonesia, (Jakarta, Kencana Prenada Media Group, Cet. I, Ed. Pertama 2006

Abdurrahman, Kompilasi Hukum Islam di Indonesia, Jakarta: Akademika Pressindo, 2010

Ahmad al Hajjiy al Kurdiy, Al Qawa'id al Fiqhiyatu al Kulliyah, Cet. I, Kuwait, Al Dar Al Thahiriyah, 2019 M/1440

Ahmad Warson Munawwir, Al-Munawwir, Surabaya, Pustaka Progressif, 1997

Akh. Minhadji, "Reorientasi Kajian Ushul Fiqh", dalam Restrukturisasi Metodologi Islamic Studies Mazhab Yogyakarta, Yogyakarta, Suka Press, 2007.

Blood, R,O, Marriage ( $2^{\text {nd }}$ ed), New York, The Free Press, 1969

Departeman Agama RI, Al-Qur'an Tajwid dan Terjemah, (Jakarta: Penerbit Maghfirah Pustaka, 2006

Dr. H. Saifudin zuhri, M.Ag, Sanksi Pidana Sebagai Pendidikan Bagi Pelaku Nikah Siri Dalam Perspektif Hukum Islam, Semarang, 2012

Enseklopedia Pengetahuan Al-Qur'an dan Hadis, Jakarta, Kamil Pustaka, 2013

http://tribunnews.com/seleb/2013/04/24/anak-machica-mochtar-tak-dapat-warisan$\underline{\text { moerdiono }}$

Intruksi Presiden Nomor 1 Tahun 1991, Tentang Kompilasi Hukum Islam

Nasotion, Khoiruddin, Hukum Perdata (Keluarga) Islam Indonesia dan Perbandingan Hukum Perkawinan Di Dunia Muslim, Yogyakarta: Academia Tazzafa, 2009

Maruarar Siahaan, Hukum Acara Mahkamah Konstitusi, Jakarta, Sinar Grafika, 2012

Masyfuk Zuhdi, Nikah Siri, Nikah Di Bawah Tangan Dan Status Anaknya Menurut Hukum Islam Dan Hukum Positif, dalam Mimbar Hukum, Nomor 28 Tahun VII, September - Oktober 1996, Jakarta, Al Hikmah Dan DITBINBAPERA Islam

Moh Idris Ramulyo. Hukum perkawinan Islam Suatu Analisis dari Undang-Undang Nomor 1 Tahun 1974 dan Kompilasi Hukum Islam. Jakarta : Bumi Aksara, 1996.

Muhammad Amin Suma, Hukum Keluarga Islam Di Dunia Islam, Jakarta, PT Raja Grafindo Persada, 2004

Muhammad Utsman Syabir, al-Qawa'id al-Kulliyah wa al-Dlawabith al-Fiqhiyah, Urdun, Dar al Nafais, 2007

M. Ali Hasan, Pedoman Hidup Berumah Tangga Dalam Islam, Jakarta: Prenada Media, 2003

M. Nurul Irfan, Nasab dan Status Anak dalam Hukum Islam, Jakarta, Amzah, 2013 
Peraturan Pemerintah Nomor 9 Tahun 1975 tentang Pelaksanaan Undang-Undang Nomor 1 Tahun 1974 tentang Perkawinan

Putusan MK No. 46/PUU-VIII/2010

Sujari Dahlan, Fenomena Nikah Siri, Cet. I, Pustaka Progresif, 1996

Undang-Undang Dasar 1945, Amandemen Ke- III

Undang-undang Nomor 22 Tahun 1946 jo Undang-undang Nomor 32 Tahun 1954 tentang Pencatatan Nikah, Talak dan Rujuk di Seluruh Daerah Luar Jawa dan Madura

Undang-undang RI No. 1 Tahun 1974 Tentang perkawinan \& KHI Cet. II, Bandung: Citra Umbara, 2013

Yusuf Hanafi, Kontroversi Perkawinan Anak Di Bawah Umur, Bandung, Mizan, 1986 